\section{QIJEI}

\author{
International \\ Journal for \\ Educational \\ Integrity
}

\title{
Editorial, Volume 5(2)
}

Integrity is fundamental to everyone involved in education - students, parents, teachers, lecturers, administrators and future employers, as well as the general public. It is hardly surprising therefore, that research on educational integrity continues to gather momentum, as evidenced by the growing number of conferences and seminars on this subject around the world. I am very pleased to report that while student cheating and plagiarism continue to be topics of interest, practitioners and researchers are also exploring the broader, social context and the changing, globalised and increasingly commercialised nature of education itself.

The current issue of the International Journal for Educational Integrity is introduced by William Astore's Plenary Address from the Annual International Center for Academic Integrity Conference, held at Washington University in St Louis, Illinois in October this year. Astore spoke boldly to conference delegates of the 'wider dimensions of academic integrity', using anecdotes from his own experience as a military instructor at the Air Force Academy in Colorado Springs, and as a history professor at the Pennsylvania College of Technology. He convincingly argued that systemic breaches of integrity are far more harmful than individual lapses such as student cheating because they compromise the institution as a whole. In his Address, Astore was openly critical of the marketisation of higher education, a topic which was also explored at the $4^{\text {th }}$ Asia-Pacific Conference on Educational Integrity: Creating an Inclusive Approach, held in September at the University of Wollongong in NSW, Australia.

The four best refereed papers from the Asia-Pacific Conference are included in this issue of the IJEI. Kim Sawyer from the University of Melbourne, and Jackie Johnson and Mark Holub from the University of Western Australia, provide a candid analysis of the decline in academic standards and integrity in Australian higher education. This paper provides a thorough overview of recent changes in Australian higher education. As Richard Davis commented in his review, "Critics of the modern university face an uphill task. Accused of advocating old, inefficient ways and lamenting a decadent past, they are easily silenced by self-satisfied colleagues enjoying their large research grants and consultancies. Some critics can do little more than condemn local personalities. All would be well if the vice-chancellor was less authoritarian or the university council less mean in its refusal of salary increases. The strength of the current paper lies in its remorseless analysis of the system which developed inexorably from the government's determination to educate more students while cutting its higher education costs. The 'new' corporate market-based university replaced the 'old' university dedicated to the ideals of free enquiry and education as an end in itself".

Moving from the broad educational context to specific practices, the next four papers in this issue investigate issues of learning, teaching, assessment and adjudication. Clair Hughes from the University of Queensland addresses an apparent shortfall in Australian universities' implementation of 'Graduate Attributes' (GA), including the GA relating to ethical conduct. Hughes maintains that to authentically operationalise GAs, much more is needed than simply mapping specific attributes against existing programs and courses. Hughes argues for a whole of programme approach, the explicit inclusion of ethics in course teaching and assessment plans, and provides specific examples of how this may be achieved.

The International Journal for Educational Integrity is available online at:

http://www.ojs.unisa.edu.au/journals/index.php//JEl/

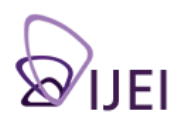


Jon Yorke, Kathryn Lawson and Graham McMahon from Curtin University of Technology in Western Australia, ask how those who adjudicate breaches of academic integrity can reliably determine 'intent' in cases of plagiarism. The authors draw on a desktop study of institutional policies and procedures in 20 universities from Australia, US, Singapore, Hong Kong, India and the UK to analyse the way that 'intent' is defined and determined. Their findings indicate that despite the espoused significance of 'intent' in determining outcomes for alleged academic misconduct in many policies, there is inconsistency in the way that it is treated. The authors provide a preliminary series of 'probability factors' which might be used to determine 'intent' and call for further research in this little explored aspect of academic integrity.

Grace McCarthy and Ann Rogerson from the University of Wollongong in NSW, Australia, share the results of a trial at the Sydney Business School where 61 international students were encouraged to use 'originality reports' provided by the software program Turnitin to assess the originality of their own work and thus avoid inadvertent plagiarism. In conjunction with hands-on support from teaching staff, students were permitted to submit as many drafts as necessary to Turnitin, with the result that all final submissions had a text match of $5 \%$ or less. As a consequence of the positive results of the trial, the use of Turnitin as a drafting mechanism, coupled with an extensive program of embedded support and supplementary workshops, has now been mandated for all subjects. The authors share further qualitative and quantitative data to support their thesis that "the use of text-matching software can be a powerful aid to help students improve their writing and to help academic staff identify potential plagiarism".

The final paper in this issue is the only one not previously presented at one of the international conferences on academic integrity held during 2009. Mary Davis and Jude Carroll from Oxford Brookes University, using data collected over three years from cohorts of international students in the UK, also explore the role of text-matching software in plagiarism education, with a focus on the importance of formative feedback through tutorial intervention. As one part of an overall educative approach, students worked hand in hand with their tutors to read and interpret the Originality Reports of ungraded drafts of assignments prior to final submission. Students were also surveyed at the end of the module to ascertain their perceptions of the value of using Turnitin in this way. The data indicated that the approach taken at Oxford Brookes University resulted in reductions in the amount of plagiarism, over-reliance on sources, citations errors and insufficient paraphrasing. This study provides an example of best practice in the educational use of text-matching software and provides a potential counter to those who are concerned that the sole function of such software is to police and punish students.

I hope that you enjoy this issue of the International Journal for Educational Integrity, and invite you to submit a paper for review directly to me at tracey.bretag@unisa.edu.au or respond to the Call for Papers for Volume 6(2) below.

\section{Tracey Bretag, IJEI Editor}

December 2009

\section{Call for papers, Volume 6(2) 2010}

Special issue of IJEI on 'digital technologies and educational integrity' Edited by Chris Moore and Ruth Walker

This special issue seeks articles that address the impact of digital technologies on educational integrity. Many different terms have emerged in an attempt to capture the shifting terrain of media and users in various networked environments: 'social', 'participatory', 'user-generated' or simply 'new' media. Common to the online and 
interactive spaces of Web2.0 is the challenge of technologies and practices that are capable of changing the way we teach, learn, and share knowledge. How can we best engage and support students and colleagues coming to terms with the dynamics of these technologies and the development of new literacies?

We are particularly interested in innovative research from scholars in cultural and media studies and/or the scholarship of teaching and learning, and welcome interest from the other disciplinary researchers, who might consider a broad range of questions about digital technologies that critically unpack the conversation about education integrity that goes beyond preoccupation with plagiarism and research ethics. Critical voices of concern, examples of best practice and consideration of the perceived impact of digital technology on institutional boundaries are keenly sought as is research exploring the collaborative approaches to social and participatory media that challenge conceptions about authorial identity and scholarly writing practices. Research examining the development of new literacies that celebrate the appropriation, adaptation and transformation of source material would fit well within the scope of this special issue.

Abstract due date: 31 March 2010

Full paper deadline: 1 July 2010

Special issue release date: December 2010

Send all enquiries and 500 word abstract to the guest editors at ruthwalker@uow.edu.au

\section{With thanks to our reviewers in 2009:}

Kate Andre, University of South Australia

Peter Bowden, University of Sydney

Kylie Brass, University of Western Sydney

Deborah Churchman, University of South Australia

Geoffrey Crisp, University of Adelaide

Richard Davis, University of Tasmania

John Dearn, Australian National University

Fiona Duggan

Lawrence B. Ebert

Teddi Fishman, Clemson University

Neera Handa, University of Western Sydney

Beverley Kokkin, University of South Australia

Margaret Lightbody, University of Adelaide

Nancy Matchett, University of Colorado

Paul Moore, University of Wollongong

Gerry Mullins, University of Adelaide

Nicholas Proctor, University of South Australia

Wendy Sutherland-Smith, Monash University

Daniel Wueste, Clemson University 